\title{
Use of radon for evaluation of atmospheric transport models: Sensitivity to emissions
}

\author{
Mohan L. Gupta ${ }^{(1)}$, Anne R. Douglass ${ }^{(2)}$, S. Randolph Kawa ${ }^{(2)}$ and Steven Pawson ${ }^{(3)}$
}

To be submitted to Tellus-B

\section{Summary}

This paper presents comparative analyses of atmospheric radon $(\mathrm{Rn})$ distributions simulated using different emission scenarios and the observations. Results indicate that the model generally reproduces observed distributions of $\mathrm{Rn}$ but there are some biases in the model related to differences in large-scale and convective transport. Simulations presented here use an off-line three-dimensional chemical transport model driven by assimilated winds and two scenarios of $\mathrm{Rn}$ fluxes (atom $\mathrm{cm}^{-2} \mathrm{~s}^{-1}$ ) from ice-free land surfaces: (A) globally uniform flux of 1.0, and (B) uniform flux of 1.0 between $60^{\circ} \mathrm{S}$ and $30^{\circ} \mathrm{N}$ followed by a sharp linear decrease to 0.2 at $70^{\circ} \mathrm{N}$. We considered an additional scenario (C) where Rn emissions for case A were uniformly reduced by $28 \%$. Results show that case A overpredicts observed $\mathrm{Rn}$ distributions in both hemispheres. Simulated northern hemispheric (NH) Rn distributions from cases B and C compare better with the observations, but are not discernible from each other. In the southern hemisphere, surface $\mathrm{Rn}$ distributions from case $\mathrm{C}$ compare better with the observations. We performed a synoptic scale source-receptor analysis for surface $\mathrm{Rn}$ to locate regions with ratios $\mathrm{B} / \mathrm{A}$ and $\mathrm{B} / \mathrm{C}$ less than 0.5 . Considering an uncertainty in regional $\mathrm{Rn}$ emissions of a factor of two, our analysis indicates that additional measurements of surface Rn particularly during AprilOctober and north of $50^{\circ} \mathrm{N}$ over the Pacific as well as Atlantic regions would make it possible to determine if the proposed latitude gradient in $\mathrm{Rn}$ emissions is superior to a uniform flux scenario.

${ }^{(1)}$ GEST/GSFC NASA, Code 916, Greenbelt, MD 20771

${ }^{(2)}$ NASA GSFC, Code 916, Greenbelt, MD 20771

${ }^{(3)}$ GEST/GSFC NASA, GMAO, Greenbelt, MD 20771 


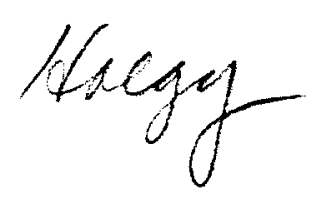

Use of radon for evaluation of atmospheric transport models:

Sensitivity to emissions

Mohan L. Gupta ${ }^{(1)}$, Anne R. Douglass ${ }^{(2)}$, S. Randolph Kawa ${ }^{(2)}$ and Steven Pawson ${ }^{(3)}$

${ }^{(1)}$ GEST/GSFC NASA, Code 916, Greenbelt, MD 20771

${ }^{(2)}$ NASA GSFC, Code 916, Greenbelt, MD 20771

${ }^{(3)}$ GEST/GSFC NASA, GMAO, Greenbelt, MD 20771

To be submitted to Tellus-B

February 03, 2004 


\section{ABSTRACT}

We present comparative analyses of atmospheric radon $(R n)$ distributions simulated using different emission scenarios and the observations. Results indicate that the model generally reproduces observed distributions of $\mathrm{Rn}$ but there are some biases in the model related to differences in large-scale and convective transport. Simulations presented here use an off-line three-dimensional chemical transport model driven by assimilated winds and two scenarios of $\mathrm{Rn}$ fluxes (atom $\mathrm{cm}^{-2} \mathrm{~s}^{-1}$ ) from ice-free land surfaces: (A) globally uniform flux of 1.0, and (B) uniform flux of 1.0 between $60^{\circ} \mathrm{S}$ and $30^{\circ} \mathrm{N}$ followed by a sharp linear decrease to 0.2 at $70^{\circ} \mathrm{N}$. We considered an additional scenario (C) where Rn emissions for case A were uniformly reduced by $28 \%$. Results show that case $A$ overpredicts observed $R n$ distributions in both hemispheres. Simulated northern hemispheric (NH) Rn distributions from cases B and C compare better with the observations, but are not discernible from each other. In the southern hemisphere, surface $\mathrm{Rn}$ distributions from case $\mathrm{C}$ compare better with the observations. We performed a synoptic scale source-receptor analysis for surface $\mathrm{Rn}$ to locate regions with ratios $\mathrm{B} / \mathrm{A}$ and $\mathrm{B} / \mathrm{C}$ less than 0.5 . Considering an uncertainty in regional Rn emissions of a factor of two, our analysis indicates that additional measurements of surface Rn particularly during AprilOctober and north of $50^{\circ} \mathrm{N}$ over the Pacific as well as Atlantic regions would make it possible to determine if the proposed latitude gradient in $\mathrm{Rn}$ emissions is superior to a uniform flux scenario. 


\section{INTRODUCTION}

Evaluation of the representation of large- and sub-scale transport processes in an atmospheric model is a prerequisite for its application to study chemistry-climate interactions. Long lived tracers such as $\mathrm{CFCs}_{\text {and }} \mathrm{SF}_{6}$ are generally used to evaluate large-scale atmospheric transport features such as interhemispheric exchange (Prather et al., 1987; Denning et al., 1999; Gupta et al., 2001). Radon $\left({ }^{222} \mathrm{Rn}\right.$, or simply $\left.\mathrm{Rn}\right)$, characterized by its short radioactive decay time constant $\left(\tau_{1 / 2}=3.825\right.$ days $)$ and primarily land-based emissions, has been extensively used as a tracer for study of sub-scale convective and synoptic transport processes in the troposphere (Liu et al., 1984; Dentener et al., 1999; Chevillard et al., 2002). Radon has been used for model intercomparison studies (Jacob et ai., 19997; Rasch et ai., 2000), assessment of convective parameterizations (Mahowald et al., 1995; Allen et al., 1996), and evaluation of model transport of continental air to remote oceanic locations (Heimann et al., 1990; Balkanski and Jacob, 1990).

Emissions of $\mathrm{Rn}$ from radioactive decay of radium in soils are known to be highly variable. Factors controlling $\mathrm{Rn}$ emissions include the ${ }^{226} \mathrm{Ra}$ concentration and the physical characteristics of soil affecting its escape into the atmosphere (Turekian et al., 1977; Nazaroff, 1992). Jacob and Prather (1990) and Genthon and Armengaud (1995) have derived algorithms to account for some of the variations in $\mathrm{Rn}$ emissions. Observations used to develop these algorithms are limited and do not uniformly represent the entire globe, therefore a simple emission rate of 1.0 atom cm $\mathrm{cm}^{-2}$ over the ice-free land surfaces between $60^{\circ} \mathrm{S}$ and $60^{\circ} \mathrm{N}$ has been widely used (Jacob et al., 1997; Rasch et al., 2000]. This emission rate is considered to be accurate to within $25 \%$ globally and within a factor of two regionally (see Jacob et al., 1997 and references therein). Also, this Rn flux falls between two other estimates of 0.72 atom $\mathrm{cm}^{-2} \mathrm{~s}^{-1}$ and 1.2 atom $\mathrm{cm}^{-2} \mathrm{~s}^{-1}$, suggested by Lambert et al. (1982) and Turekian et al. (1977). Various models 
have simulated atmospheric distributions of $\mathrm{Rn}$ using this emission rate and assimilated meteorology and compared them against observed surface concentrations and vertical profiles (e.g., Dentener et al., 1999 and Taguchi et al., 2002). Oceanic contributions to the Rn flux are considered negligibly small $\left(0.005\right.$ atom $\left.\mathrm{cm}^{-2} \mathrm{~s}^{-1}\right)$.

Recently, Conen and Robertson (2002) reported that land-based Rn fluxes decrease linearly from 1.0 atom $\mathrm{cm}^{-2} \mathrm{~s}^{-1}$ at $30^{\circ} \mathrm{N}$ to 0.2 atom $\mathrm{cm}^{-2} \mathrm{~s}^{-1}$ at $70^{\circ} \mathrm{N}$. Their conclusion was based on indirect estimates of $\mathrm{Rn}$ emissions. The authors speculated that the northward decrease in $\mathrm{Rn}$ emissions could be due to more organic soils with decreasing radium content and shallow water tables. They emphasized the potential importance of this finding in validation of atmospheric transport models. This revised estimate modifies $R n$ emission from $59 \%$ of the northern hemispheric (NH) land-cover between $31^{\circ} \mathrm{N}$ and $71^{\circ} \mathrm{N}$.

Here, we investigate the impact of different emission estimates of $\mathrm{Rn}$ on simulated atmospheric distributions. We compare simulated $\mathrm{Rn}$ distributions against corresponding observations. This comparative analysis will also evaluate treatment of physical processes and meteorological inputs to the model that are responsible for long-range as well as vertical transport of $\mathrm{Rn}$ in the atmosphere.

\section{MODEL SIMULATIONS}

All the simulations presented here were performed using the Goddard Space Flight Center (GSFC) off-line three-dimensional parameterized chemistry and transport model (PCTM) (Nielsen and Douglass, 2001). Meteorological fields (surface pressure, temperature and winds), and convective and diffusive fluxes input to PCTM were taken from a reanalysis run of the Goddard Earth Observation System, version 4 (GEOS-4) data assimilation system given at a 
resolution of $2.5^{\circ} \times 2^{\circ}$ with 55 hybrid sigma-pressure levels between the surface and $80 \mathrm{~km}$. GEOS-4 is an updated version of the Finite-Volume Data Assimilation System (FVDAS) used by Douglass et al. (2003). The time dependent tracer mass continuity equation was solved at $15-$ minute time intervals using linearly interpolated wind fields drawn from six-hour archives of GEOS-4 meteorology. Advection was calculated using a flux-form semi-Lagrangian scheme (Lin and Rood, 1996) on the GEOS-4 grid. A pressure fixer, applied following Prather et al. (1987), adjusts the horizontal winds slightly to remove the mass increase that results from inconsistency between the forecast and observed surface pressures used in the assimilation process. A semæi implicit numerical scheme was applied for convective tracer transport based on the three-dimensional cloud mass flux produced by the FVDAS.

Atmospheric $\mathrm{Rn}$ simulations were performed using analyzed meteorology for 1993 and 1994. For both years, twcemi ssion scenarios were used: (A) 1.0 atom $\mathrm{cm}^{-2} \mathrm{~s}^{-1}$ (Jacob et al., 1997) and (B latitude dependent emissions suggested by Conen and Robertson (2002). Fractional landbased emissions were uniformly applied in coastal and island-containing model grids using a high resolution $\left(1 / 6^{\circ} \times 1 / 6^{\circ}\right)$ surface topography. No alterations in land-based $\mathrm{Rn}$ fluxes in these model grids were introduced even though there is an evidence of lower $\mathrm{Rn}$ emanation rates at island of Hawaii due to water saturation (Whittlestone et al., 1996). Also, surface Rn emissions were zero for model grids with surface temperature below freezing point. We lack knowledge of the temporal variations in land-based $\mathrm{Rn}$ sources, therefore, constant emissions were applied at each time step. For both cases, the model was allowed to spin-up for three months before comparing the results with observations. We also considered another $\mathrm{Rn}$ emission rate of 0.72 atom $\mathrm{cm}^{-2} \mathrm{~s}^{-1}$, as proposed by Lambert et al. (1982), by proportionally scaling down $\mathrm{Rn}$ 
concentrations from case A. This model scenario is termed as C. For cases A, B and C, annual global $\mathrm{Rn}$ emissions were $62.1,55.3$ and 44.7 moles respectively.

To investigate the impact of latitudinal gradient in $\mathrm{Rn}$ emissions, we concentrate on its NH distributions. Validation was performed by comparison with observations from the same period as the analyzed wind [1993-94]. Measured Rn vertical profiles over Moffett Field during 1994 (Kritz et al., 1998) and from the North Atlantic Regional Experiment (NARE) Intensive1993 (Zaucker et al., 1996) were compared with model profiles for all three emission scenarios. Surface measurements of Rn over Bermuda $\left(64.45^{\circ} \mathrm{W}, 32.2^{\circ} \mathrm{N}, 28 \mathrm{~m}\right.$ asl; BER) for 1993 reported by Environmental Measurement Laboratory (EML) (Hutter et al., 1995) were also used. EML reports data for BER at a 60-minute time interval. Even thoüh $R$ a data for other northern hemispheric stations e.g. island site (Mauna Loa) and continental sites (Freiburg and Schauinsland, Germany) are also available, we considered Bermuda as a representative site for model-data comparison because of its remote location, low surface elevation and negligible local emissions (surface land area $=53 \mathrm{~km}^{2}$ ). For the purpose of model evaluation to examine the influence of uniform reduction in surface emissions, we also include comparison between simulated and observed surface $\mathrm{Rn}$ for 1993 at twosouthern hemispheric (SH) stations: Amsterdam Island $\left[77.34^{\circ} \mathrm{E}, 37.5^{\circ} \mathrm{S}, 50 \mathrm{~m}\right.$ asl; AMS $]$ and Cape Grim $\left[144.41^{\circ} \mathrm{E}, 40.41^{\circ} \mathrm{S}, 94 \mathrm{~m}\right.$ asl; CGA] following Dentener et al. (1999). CGA is located on the coastal site of Australia and AMS is remotely located in the Indian Ocean with land surface land area of $61 \mathrm{~km}^{2}$.

\section{RESULTS AND DISCUSSION}

\section{A. Comparison for $R \mathbf{n}$ vertical profiles}

a. Vertical profiles during the NARE-1993 campaign 
Simulated and observed $\mathrm{Rn}$ for the NARE Intensive period 16-31 August, 1993 are compared in Fig. 1. Sixty-six Rn samples were collected between the boundary layer and $5.5 \mathrm{~km}$ over the North Atlantic Ocean and the continent in the vicinity of Nova Scotia and New Brunswick, Canada (Zaucker et al., 1996). To facilitate the comparison, observed Rn concentrations and corresponding modeled values were divided into three subdivisions: $0-2 \mathrm{~km}$ for the marine boundary layer (MBL); 0-2 km for continental boundary layer (BL); and free troposphere (FT). The total numbers of samples in the MBL, BL and FT subdivisions are 28, 13 and 25 respectively. Average concentrations and $\pm 1 \sigma$ standard deviation for each division were computed for analysis.

Case A predicts larger than observed Rn concentrations for all three regions. Modeled Rn concentrations from cases B and C closely correspond to observed values, particularly for MBL and FT. For case B, the agreement is within $\pm 5 \%$ and for case $\mathrm{C}$, it is within -3 and $16 \%$. For the BL, cases B and C overpredict observed average Rn by $27 \%$ and $38 \%$ respectively. This stated discrepancy could be due to uncertainty in $\mathrm{Rn}$ emissions and insufficient vertical transport of continental boundary layer airmass to the free troposphere. The latitudinal band covered during the NARE-1993 Intensive is $42^{\circ} \mathrm{N}-46^{\circ} \mathrm{N}$ where the Rn flux was reduced by $24-32 \%$ in case $\mathrm{B}$. The mean value of this reduction corresponds to the decrease in global $\mathrm{Rn}$ surface emissions for case $\mathrm{C}$ as compared to that for case $\mathrm{A}$. This comparison indicates that although the ratio (B/C) for integrated NH Rn source strength is 1.25 , the simulated $\mathrm{Rn}$ distributions from both cases for the NARE geographic area are not clearly distinct from each other.

\section{b. Vertical profiles over Moffett Field during 1994}


A comparison between modeled and observed $\mathrm{Rn}$ concentrations over Moffett Field $\left(37.4^{\circ} \mathrm{N}, 122.0^{\circ} \mathrm{W}\right)$ is shown in Fig. 2. Observations are adopted from Kritz et al. (1998), who report $\mathrm{Rn}$ profiles from the surface to $11.5 \mathrm{~km}$ obtained from 127 samples on $11 \mathrm{flights}$ during June 3-August 16, 1994. We averaged Rn concentrations corresponding to three segments of vertical profiles: (1) 0-2 km; (2) $2-6 \mathrm{~km}$; and (3) 6-11.5 km. All three emission scenarios overestimate observed average $\mathrm{Rn}$ in the lowest $2 \mathrm{~km}$ of the atmosphere, however, this comparison is the worst for case A. In the model, Moffett Field is located in the coastal grid (with $64 \%$ of land cover) which, as stated earlier, may have lower Rn emanation rate than what is considered here. At the latitude of Moffett Field, reductions in Rn emission for cases B and C are $15 \%$ and $28 \%$ respectively relative to case $A$. For the layer between $2-6 \mathrm{~km}, \mathrm{Rn}$ distributions from all cases closely follow each other within $\pm 1 \sigma$ deviation around the mean. Besides atmospheric mixing, a combination of two factors: (1) higher magnitude of NH emissions, and (2) a relatively smaller reduction in local surface flux at Moffett field for case B resulted in its distributions thata re not different from those of case C.

Because of simulated excessive Rn near the surface, irrespective of emission scenarios, model underpredicts observed $\mathrm{Rn}$ at high altitudes. This discrepancy may be due to insufficient long-range transport and possible existence of high $\mathrm{Rn}$ emission from East Asian region (Dentener et al., 1999) which is not considered here. Doubling of convective fluxes in model simulation improved the results by up to $15 \%$ at high altitudes. Model simulations for case B with regionally tagged emissions for Indo-China and North American regions show that, above 6 $\mathrm{km}$, more than $50 \%$ of the Rn over Moffett Field originates in the Indo-China region (Fig. 3). This result is qualitatively consistent with the conclusions of Kritz et al. (1990) and Stockwell et 
al. (1998). Togetherthe se regional sources account for more than $80 \%$ of total atmospheric $\mathrm{Rn}$ simulated over the Moffett Field.

\section{B. Comparison for surface Radon}

\section{a. Northern Hemisphere}

We compare modeled and observed Rn surface concentrations for NH station BER. Bermuda is downwind of North America and routinely experiences strong influence of its $\mathrm{Rn}$ sources due to westerly flow. As should be expected due to use of assimilatedmeteorological fields, the model often captures observed synoptic scale variability in surface $\mathrm{Rn}$ as shown for June in Fig. 4. In this figure, we used model results for case B, however, it should be emphasized that synoptic variability in simulated $\mathrm{Rn}$ is independent of choice of emission scenario. However, due to differences in emission intensities, the simulated extreme $\mathrm{Rn}$ concentrations during these synoptic events differ significantly. The model failed to simulate a prolonged event of high $\mathrm{Rn}$ concentration observed around Julian days 169 and 171. It also predicts excessive $\mathrm{Rn}$ around Julian days 160-163, but generally corresponds with a data within a factor of two. Radon simulations performed using assimilated winds from an earlier version of GEOS exhibited similar nature of synoptic scale variability at this location (Alen et al. , 1996).

For comparison of modeled and observation data for BER over a year, surface $\mathrm{Rn}$ was averaged each month. The model produces the general features of the observed monthly variation in surface $\mathrm{Rn}$ at $\mathrm{BER}$ (Fig. 5). This figure also displays $\pm 1 \sigma$ deviation about the mean of the observations. Standard error for the observation is calculated to be very small. Lower $\mathrm{Rn}$ concentrations during late summer and fall are due to the formation of the so-called 'Bermuda High' which prevents outside air from entering into the high pressure region. 
During the first half of the year, case A consistently overpredicts observed monthly averaged surface $\mathrm{Rn}$ at BER. However, its monthly mean values liewithin the $+1 \sigma$ deviation around the observed mean values, except for April. Simulated surface Rn concentrations from cases B and C closely follow each other and are in close agreement with the observed values (with correlation coefficients of 0.60 and 0.55 respectively) despite a reduction of only $6 \%$ in surface flux at $33^{\circ} \mathrm{N}$ for case B as compared to $28 \%$ for case C. It should be noted these reductions in $\mathrm{Rn}$ emissions are within the range of uncertainties in regional and global sources. However, in the absolute sense, this comparison reinforces previous conclusions that despite a difference in NH source strength in Rn emissions for cases B and C, their simulated $\mathrm{Rn}$ distributions do not significantly differ from each other due to mixing of aimass from other latitudes.

\section{b. Southern hemisphere}

In this section, we present comparison between simulated and observed surface $\mathrm{Rn}$ for the two southern hemispheric stations, AMS and CGA. Fig. 6 shows a comparison of synoptic changes in observed and simulated surface Rn from case B at (a) CGA for Marchand (b) AMS for July. Similar to that for BER station, at both sites the model captures most events of observed high and low surface Rn activities. In case of AMS, the model successfully simulates the baseline Rn surface concentrations and events of radonic storms. In the absence of local emissions due to very small surface land area, the good comparison of these characteristic features of surface Rn at AMS establishes a confidence in model's ability to accurately simulate the transport of continental airmass to the remote sites.

Figure 7 shows a comparison between simulated and observed monthly averaged surface $\mathrm{Rn}$ at (a) CGA and (b) AMS. This figure also displays $\pm 1 \sigma$ deviation about the mean for 
observation. Standard error for the observation is calculated to be very small. At CGA, the model reproduces monthly variation in observed surface $\mathrm{Rn}$ within \pm 1 standard deviation from the mean except for the October month. For this month both cases A and B overpredict the surface Rn. In general, simulated monthly mean $\mathrm{Rn}$ from case $\mathrm{C}$ closely follows corresponding observed surface values at CGA. For case $\mathrm{C}$, coefficient of correlation between monthly averaged observed and simulated surface $\mathrm{Rn}$ is 0.68 . There seems to be a tendency in the model to underpredict the observed mean Rn during May and June when corresponding values from all three cases are significantly lower.

At AMS, all cases reproduce the general features of monthly variation in observed surface Rin but overpredict its magnitude indicating insufficient ventilation of boundary layer airmass to free troposphere. This overprediction is the least for case $\mathrm{C}$ but it is within +1 standard deviation from the observed mean except for January and December. For this case, the coefficient of correlation between monthly averaged observed and simulated surface $\mathrm{Rn}$ is 0.72 . For most of the months, the simulated monthly mean surface $\mathrm{Rn}$ from cases A and B lies outside one standard deviation from the corresponding observed mean value (Fig. 7b). Combined with the inference from the earlier discussion for CGA station, this comparison shows that emission scenario from case $\mathrm{C}$ is better suited for simulation of $\mathrm{SH} \mathrm{Rn}$ distribution.

We performed another model simulation identical to case A except that the effect of Rn emissions due to partial land cover in coastal and island grid boxes was neglected. For the AMS site, there is no significant effect of neglecting the local emissions due to its small land area as shown by plus symbols in Fig. 7b. On the other hand, improper distribution of Rn emissions in the model grid containing CGA leads to overestimation of its simulated surface concentrations for the months of September-December. Similarly, for two other SH sites, Kerguelen $\left(70.15^{\circ} \mathrm{E}\right.$, 
$49.21^{\circ} \mathrm{S}, 30 \mathrm{~m}$ asl $)$ and Crozet $\left(51.52^{\circ} \mathrm{E}, 46.26^{\circ} \mathrm{S}, 150 \mathrm{~m}\right.$ asl $)$, results not shown here, model calculations indicate that local emissions can significantly affect the baseline surface Rn because of their land surface areas $\left(7215 \mathrm{~km}^{2}\right.$ and $325 \mathrm{~km}^{2}$ respectively). These results indicate that $\mathrm{Rn}$ fluxes need to be prescribed carefully in coastal and island containing model grids in order to compare to data meaningfully.

Based on comparisons with the observations presented here, this study clearly shows that the model, in general, is capable to reproduce the observed distributions of atmospheric Rn. Additionally, comparisons show that the use of either the newly proposed NH latitude-dependent Rn flux scenario (case B; Conen and Robertson, 2002) or the uniform global ice-free land-based Rn surface flux of 0.72 atom $\mathrm{cm}^{-2} \mathrm{~s}^{-1}$ (case $C$; Lambert et al., 1982) in model simulations leads to $\mathrm{NH}$ atmospheric distributions of Rn that are in good agreement with the observations. Because of the limited observation database, Rn distributions from these scenarios are not clearly discernible from each other. Case A (with continental Rn surface flux 1.0 atom $\mathrm{cm}^{-2} \mathrm{~s}^{-1}$ ) overpredicts observed Rn concentrations in both hemispheres. At SH sites, Rn distributions from case C compare better with the corresponding observations.

\section{Comparison between NH Rn distributions simulated using different emission scenarios}

In this section, we concentrate on how the atmospheric Rn distribution for emission scenario B differs from those of $\mathrm{A}$ and $\mathrm{C}$ in the $\mathrm{NH}$ on various time scales.

\section{a. Annual averaged distributions}

Fig. 8 shows the NH latitude-longitude distribution of the ratio of annually averaged surface $\mathrm{Rn}$ mixing ratios between cases $\mathrm{B}$ and $\mathrm{A}$. In this figure, we also show locations of $\mathrm{Rn}$ measurement sites that are influenced by the differences in both emission distributions. Because of Rn's short lifetime and the prescribed differences in its NH emissions, values of B/A lower 
than 1.0 are mostly confined to the $\mathrm{NH}$ and decrease towards higher latitudes (shown bysolid lines). South of $45^{\circ} \mathrm{N}$, the ratio $\mathrm{B} / \mathrm{A}$, in general, is more than 0.75 which is within the range of global uncertainty in $\mathrm{Rn}$ surface emissions. At high latitudes over continental areas this ratio is lower than 0.5 . There are two factors that contribute to this pattern of $\mathrm{B} / \mathrm{A}:$ (1) northward decline in Rn emissions, and (2) about $12 \%$ less total NH emissions for case B. After uniformly scaling down NH land-based emissions for case A by $12 \%$, values of $\mathrm{B} / \mathrm{A}$ are as low as 0.7 at high latitudes (shown by dash lines) indicating that it is not the emission strength but is the latitudinal gradient that has strong impact on the distribution of B/A. Calculated lower values of B/A persist throughout the troposphere for most of the $\mathrm{NH}$ as shown in Fig. 9. Note that the lowest value of $\mathrm{B} / \mathrm{A}$ is centcred between $55^{\circ} \mathrm{N}$ and $60^{\circ} \mathrm{N}$. At the mid-latitudes, there is a tendency of an increase in $\mathrm{B} / \mathrm{A}$ values with altitude indicating decline in impact of the latitudinal gradient in $\mathrm{Rn}$ emissions. At $50^{\circ} \mathrm{N}$ and $4 \mathrm{~km}$ altitude, annually and zonally averaged $\mathrm{Rn}$ distributions from simulations $\mathrm{B}$ and $\mathrm{C}$ would not be discernible as both ratios $\mathrm{B} / \mathrm{A}$ and $\mathrm{C} / \mathrm{A}$ are roughly equal to 0.72 .

\section{b. Source-receptor analysis on synoptic timescales}

To further identify regions where synoptic scale variations in surface $\mathrm{Rn}$ from case B can be consistently and distinctly separated from those of cases A and C, we concentrate on 184 surface receptors. These receptors were placed between latitude band of $25^{\circ} \mathrm{N}-73^{\circ} \mathrm{N}$ and longitude bands of $10^{\circ} \mathrm{W}-75^{\circ} \mathrm{W}$ (Atlantic Region), $132.5^{\circ} \mathrm{E}-180^{\circ} \mathrm{E}$ and $125^{\circ} \mathrm{W}-180^{\circ} \mathrm{W}$ (Pacific Region) as shown in Fig. 10. The size of each receptor is $7.5^{\circ} \times 6.0^{\circ}$. We sampled the simulated $\mathrm{Rn}$ distributions at these receptors from simulations A and B over the entire year at a time resolution of 15 minutes. We scaled down $\mathrm{Rn}$ distributions from case $\mathrm{A}$ at each receptor by 0.72 to generate $\mathrm{Rn}$ distributions for case $\mathrm{C}$. Considering that regional $\mathrm{Rn}$ emissions have an uncertainty of a factor 
of two, we selected only those synoptic events at each receptor where ratios $B / A$ and $B / C$ of surface $\mathrm{Rn}$ is less than 0.5 . We performed three simulations for case B in which Rn emissions were tagged for latitudinal bands: (B1) $29^{\circ} \mathrm{N}-43^{\circ} \mathrm{N}$, (B2) $43^{\circ} \mathrm{N}-57^{\circ} \mathrm{N}$ and (B3) $57^{\circ} \mathrm{N}-71^{\circ} \mathrm{N}$. The purpose of these additional simulations is to quantify relative sizes of contributions from these latitude bands during the selected synoptic events at these receptors. Here, we concentrate on simulations A and B, and B3. Our analysis indicates that during March-September, on an average $44 \%$ times each receptor placed between $50^{\circ} \mathrm{N}$ and $60^{\circ} \mathrm{N}$ in Pacific region experienced B/A ratios that were less than 0.5 . Most of these selected synoptic events occurred when contribution from region $\mathrm{B} 3$ to surface $\mathrm{Rn}$ from case $\mathrm{B}$ was morethan $50 \%$.

Figure 11 shows the percent frequency distribution of selected events each month for (a) Pacific region and (b) Atlantic region when the ratio B/A is less than 0.5 and contribution from B3 region is more than 50\%. Figure 12 displays the similar plots for percent frequency distribution for ratio B/C. There are several points that can be noted from these figures. First of all, for receptors numbered below 43 (i.e. below $43^{\circ} \mathrm{N}$ located in the Pacific region), the occurrence of the events for ratio B/A constrained by both conditions is very limited over the entire year (Fig. 11a). But, as one moves northwards up to $55^{\circ} \mathrm{N}$ (i.e. for receptor numbers $43-70$ ) this frequency increases dramatically during April-October months. For all these receptors, transport of airmass from higher latitudes played a major role in the displayed frequency pattern in $\mathrm{B} / \mathrm{A}$ ratio because difference in local emissions south of $55^{\circ} \mathrm{N}$ will not solely force this ratio to be lessthan 0.5 . There is negligible occurrence of these events all around the year for receptors numbered below 149 located in the Atlantic region below $50^{\circ} \mathrm{N}$ (Fig $11 \mathrm{~b}$ ). Above $55^{\circ} \mathrm{N}$, both conditions are met more frequently for most of the year in Pacific as well as Atlantic regions. As should be expected due to lower concentrations of surface $\mathrm{Rn}$ for case $\mathrm{C}$ relative to those for case 
A, ratio $\mathrm{B} / \mathrm{C}$ meets both conditions less frequently for receptors placed above $50^{\circ} \mathrm{N}$ for both regions (Fig 12). Note that most of the receptors between $50^{\circ} \mathrm{N}$ and $60^{\circ} \mathrm{N}$ are placed over the oceanic surface and are free from uncertainties in in-situ emissions. Based on this analysis and $\mathrm{NH}$ distribution of $\mathrm{Rn}$ emissions below $60^{\circ} \mathrm{N}$, additional surface measurements of atmospheric Rn between $50^{\circ} \mathrm{N}$ and $60^{\circ} \mathrm{N}$ (i.e. for receptors 57-84 and 149-166) over the Pacific and Atlantic regions, mainly over the oceanic sites, during April-October would make it possible to confirm or refute the latitudinal gradient in Rn source distribution (case B). We further stress that these measurements of atmospheric $\mathrm{Rn}$ must conform to the same reference to avoid any systematic biases as discussed by Colle et al. (1995).

\section{CONCLUSIONS}

We present results from a study in which simulated atmospheric distributions using three scenarios of $\mathrm{Rn}$ surface fluxes were compared with each other and with the observations. Comparisons indicate that, in general, the model reproduces observed surface and vertical profiles of atmospheric $\mathrm{Rn}$ but there are some biases in the model related to differences in largescale and convective transport. We show that a globally uniform land-based $\mathrm{Rn}$ surface flux of 1.0 atom $\mathrm{cm}^{-2} \mathrm{~s}^{-1}$ overpredicts atmospheric $\mathrm{Rn}$ in both hemispheres. Globally uniform surface flux of 0.72 atom $\mathrm{cm}^{-2} \mathrm{~s}^{-1}$ or a scenario in which emission decreases with latitude north of $30^{\circ} \mathrm{N}$ produces atmospheric distributions of $\mathrm{Rn}$ that compare well with the observed northern hemispheric distributions but are not discernible from each other. However, uniform surface flux of 0.72 atom $\mathrm{cm}^{-2} \mathrm{~s}^{-1}$ is a better candidate of $\mathrm{Rn}$ emissions in the southern hemisphere. This study shows that calibrated measurements of surface Rn between $50^{\circ} \mathrm{N}$ and $60^{\circ} \mathrm{N}$ over the Pacific and 
Atlantic regions during April-October would be able to validate the suggested latitudinal gradient in surface Rn emissions.

\section{ACKNOWLEDGEMENTS}

This work was supported by NASA's Atmospheric Chemistry Modeling and Analysis Program and the EOS IDS Program. GEOS 4 data and SP partially supported through NASA Pathfinder Datasets and Associated Science Program Grant NAG5-12162. We thank Dr. Frank Dentener for providing observed surface Rn for southern hemispheric stations.

\section{REFERENCES}

Allen, D.J., Rood, R.B., Thompson, A.M. and Hudson, R.D. 1996. Three-dimensional radon 222 calculations using assimilated meteorological data and a convective mixing algorithm, $J$. Geophys. Res., 101, 6871-6881.

Balkanski, Y.J. and Jacob, D.J. 1990. Transport of continental air to the subantarctic Indian Ocean, Tellus, 42B, 62-75.

Chevillard, A. and coauthors. 2002. Transport of ${ }^{222} \mathrm{Rn}$ using the regional model REMO: a detailed comparison with measurements over Europe, Tellus, 54B, 850-871.

Colle, R. and coauthors. 1995. An international intercomparison of marine atmospheric radon 222 measurements in Bermuda, J. Geophys. Res., 100, 16617-16638.

Conen, F. and Robertson, L.B. 2002. Latitudinal distribution of radon-222 flux from continents, Tellus, 54B, 127-133.

Denning, A.S. and coauthors. 1999. Three-dimensional transport and concentration of SF 6 : A model intercomparison study (TransCom 2), Tellus, 51B, 266-297.

Dentener, F., Feichter, J. and Jeuken, A. 1999. Simulation of the transport of $\mathrm{Rn}^{222}$ using on-line and off-line global models at different horizontal resolutions: a detailed comparison with measurements, Tellus, 51B, 573-602.

Douglass, A.R., Schoeberl, M.R., Rood, R.B. and Pawson, S. 2003. Evaluation of transport in the lower tropical stratosphere in a global chemistry and transport model, J. Geophys. Res., 108(D9), 4259, doi: 10.1029/2002JD002696. 
Genthon, C. and Armengaud, A. 1995. Radon 222 as a comparative tracer of transport and mixing in two general circulation models of the atmosphere, J. Geophys. Res., 100, 2849-2866.

Gupta, M.L., Turco, R.P., Mechoso, C.R. and Spahr, J. 2001 On-line simulations of passive chemical tracers in the University of California, Los Angeles, atmospheric general circulation model 1. CFC-11 and CFC-12, J. Geophys. Res., 106, 12401-12417.

Heimann, M., Monfray, P. and Polian, G. 1990. Modeling the long-range transport of ${ }^{222} \mathrm{Rn}$ to subantarctic and antarctic areas, Tellus, 42B, 83-99.

Hutter, A.R., Larsen, R.J., Maring, H. and Merrill, J.T. $1995 .{ }^{222} \mathrm{Rn}$ at Bermuda and Mauna Loa: local and distant sources, J. Radioanal. Nucl. Chem., 193, 309-318.

Jacob, D.J. and Prather, M.J. 1990. Radon-222 as a test of convective transport in a general circulation model, Tellus, 42B, 118-134.

Jacob, D.J. and coauthors. 1997. Evaluation and intercomparison of global atmospheric transport models using ${ }^{222} \mathrm{Rn}$ and other short-lived tracers, J. Geophys. Res., 102, 5953-5970.

Kritz, M.A., Le Roulley, J.C. and Danielsen, E.F. 1990. The China Clipper-fast advective transport of radon-rich air from the Asian boundary layer to the upper troposphere near California, Tellus, 42B, 46-61.

Kritz, M.A., Rosner, S.W. and Stockwell, D.Z. 1998. Validation of an off-line three-dimensional chemical transport model using observed radon profiles: 1. Observations, J. Geophys. Res., 103, 8425-8432.

Lambert, G., Polian, G., Sanak, J., Ardouin, B., Buisson, A., Jegou, J. and Le Roulley, J.C. 1982. Cycle du radon et de ses descendants: application à Pétude des échanges troposphèrestratosphère, Ann. Geophys., 38, 497-531.

Lin, S.-J. and Rood, R.B. 1996. Multidimensional flux form semi-Lagrangian transport schemes, Mon. Weather Rev., 124, 2046-2070.

Liu, S.C., McAfee, J.R. and Cicerone, R.J. 1984. Radon 222 and tropospheric vertical transport, J. Geophys. Res., 89, 7291-7297.

Mahowald, N.M., Rasch, P.J. and Prinn, R.G. 1995. Cumulus parameterizations in chemical transport models, J. Geophys. Res., 100, 26173-26189.

Nazaroff, W.W. 1992. Radon transport from soil to air, Rev. Geophys., 30, 137-160.

Nielsen, J.E. and Douglass, A.R. 2001. A simulation of bromoform's contribution to stratospheric bromine, J. Geophys. Res., 106, 8089-8100. 
Prather, M.J., McElroy, M.B., Wofsy, S.C., Russell, G. and Rind, D. 1987. Chemistry of global troposphere: Fluorocarbons as tracers of air motion, J. Geophys. Res., 92, 6579-6613.

Rasch, P.J. and coauthors. 2000. A comparison of scavenging and deposition processes in global models: results from the WCRP Cambridge Workshop of 1995, Tellus, 52B, 1025-1056.

Stockewell, D.Z., Kritz, M.A., Chipperfield, M.P. and Pyle, J.A. 1998. Validation of an off-line three-dimensional chemical transport model using observed radon profiles 2 . Model results, $J$. Geophys. Res., 103, 8433-8445.

Taguchi, S., lida, T. and Moriizumi, J. 2002. Evaluation of the atmospheric transport model NIRE-CTM-96 by using measured radon-222 concentrations, Tellus, 54B, 250-268.

Turekian, K.K., Nozaki, Y. and Benninger, L.K. 1977. Geochemistry of atmospheric radon and radon products, Ann. Rev. Earth Planet. Sci., 5, 227-255.

Whittlestone, S., Schery, S.D. and Li, Y. 1996. Thoron and radon fluxes from the island of Hawaii, J. Geophys. Res., 101, 14787-14794.

Zaucker, F., Daum, P.H., Wetterauer, U., Berkowitz, C., Kromer, B. and Broecker, W.S. 1996. Atmospheric ${ }^{222} \mathrm{Rn}$ measurements during the 1993 NARE Intensive, J. Geophys. Res., 101, 29149-29164. 


\section{Figure Captions}

Fig. 1. Comparison between simulated and observed Rn profiles during NARE-1993. Error bars represent $\pm 1 \sigma$ deviation from the mean.

Fig. 2. Comparison between simulated and observed Rn vertical profiles over Moffett Field for the period June 3-August 16, 1994. Error bars represent $\pm 1 \sigma$ deviation from the mean.

Fig. 3. Percent contribution of regional sources of Rn from North American and Indo-China to its vertical profile over Moffett Field during June 3-August 16, 1994. Note that combined contribution from both regional sources is more than $80 \%$ of the total $\mathrm{Rn}$ at all vertical levels.

Fig. 4. Comparison between synoptic scale variation in simulated and observed surface Rn at Bermuda for June, 1993.

Fig. 5. Comparison between simulated and observed monthly averaged surface Rn at Bermuda during 1993. Observation data were missing for September and October. Bars represent $\pm 1 \sigma$ deviation from the observed mean.

Fig. 6. Comparison between synoptic scale variations in simulated and observed surface Rn at (a) Cape Grim (CGA) for March, 1993 and (b) Amsterdam (AMS) for July, 1993.

Fig. 7. Comparison between simulated and observed monthly averaged surface Rn at (a) Cape Grim (CGA) and (b) Amsterdam (AMS) during 1993. Bars represent $\pm 1 \sigma$ deviation from the observed mean. Plus symbols correspond to surface $\mathrm{Rn}$ distribution from case A when fractional land/ocean covers were neglected.

Fig. 8. Horizontal cross-section of the ratio B/A (solid lines) for annually averaged surface Rn. The contour levels decrease northwards with an interval of 0.1 . Corresponding ratios involving case A in which its $\mathrm{NH}$ Rn surface fluxes were uniformly reduced by $12 \%$ are shown by dash lines. Also shown are locations of some of the NH Rn measurement sites affected by differences between emissions for cases $\mathrm{A}$ and $\mathrm{B}$.

Fig. 9. Zonally averaged distribution of ratio B/A for simulated annually averaged Rn. 
Fig. 10. Geographical locations of 184 regional surface receptors placed within Pacific and Atlantic regions between $25^{\circ} \mathrm{N}$ and $73^{\circ} \mathrm{N}$. For each region, receptors are identified by their serial number which increases from left to right and from bottom to top.

Fig. 11. Monthly variations in percent frequency distribution of surface $\mathrm{Rn}$ events at receptors placed over (a) Pacific and (b) Atlantic regions. Contour levels on these plots are 5, 15 , $25,50,75$ and 95 . These events are characterized by ratio B/A less than 0.5 and more than $50 \%$ contribution from region $\mathrm{B} 3\left(57^{\circ} \mathrm{N}-71^{\circ} \mathrm{N}\right)$. Vertical dash lines encloses latitude band of $49^{\circ} \mathrm{N}-61^{\circ} \mathrm{N}$. Latitude correspondence of surface receptors is shown in Fig 10.

Fig. 12. Same as Fig. 11 but for the percent frequency distribution of occurrence of ratio C/A less than 0.5 . 


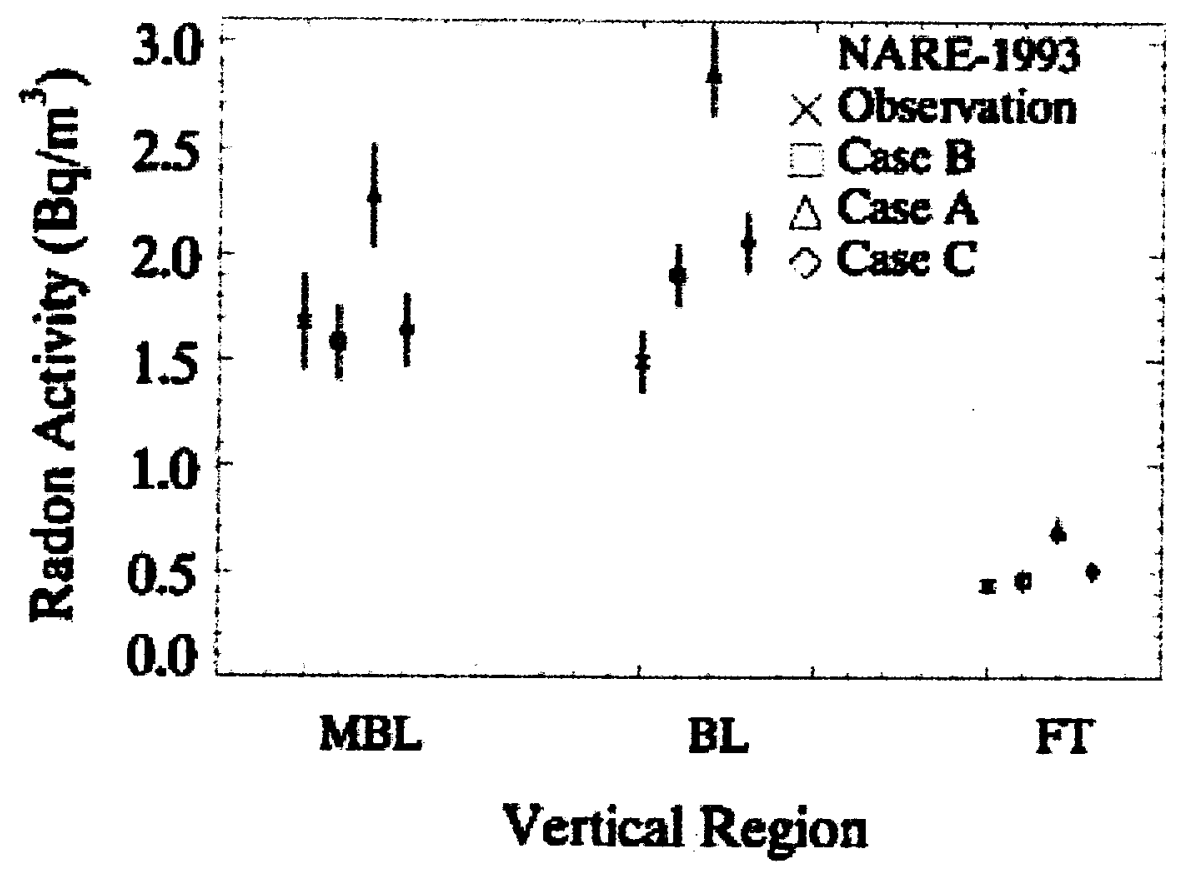

figl 


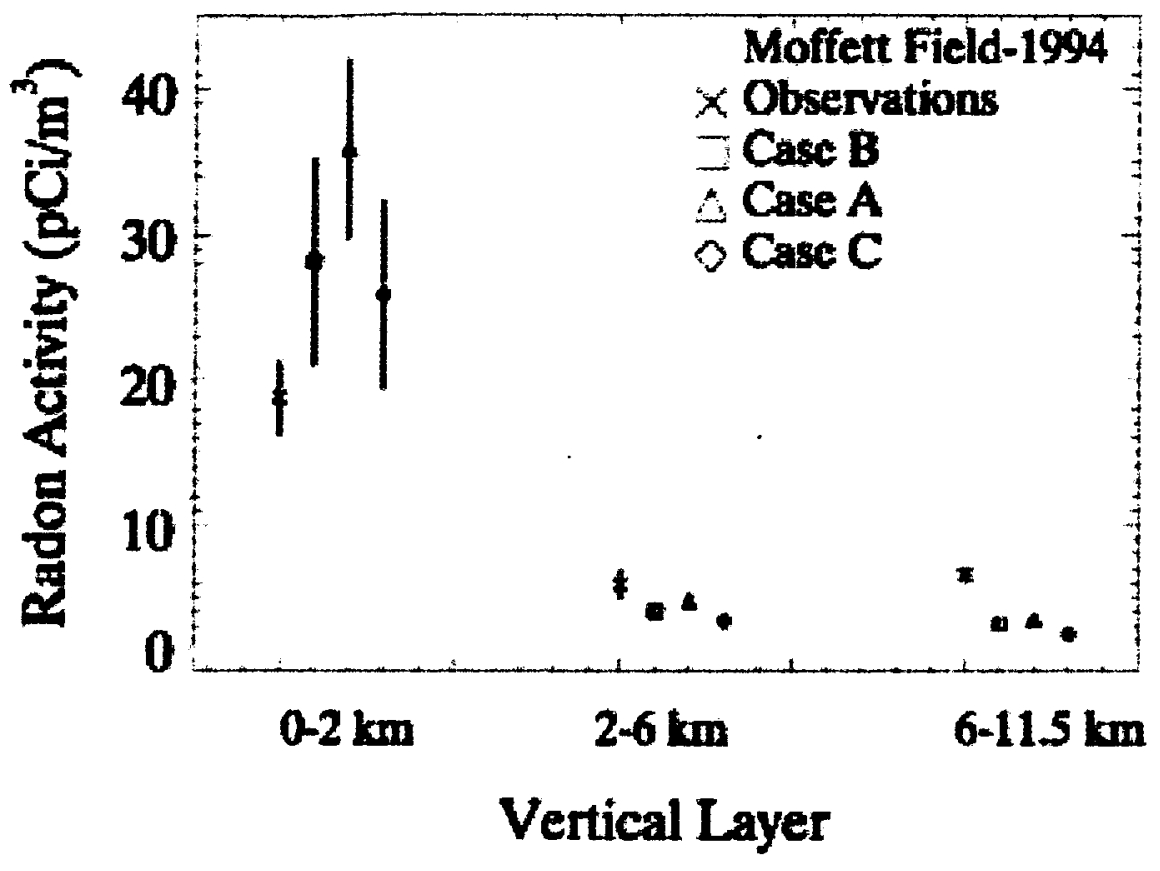

$(\sin )^{2}$ 


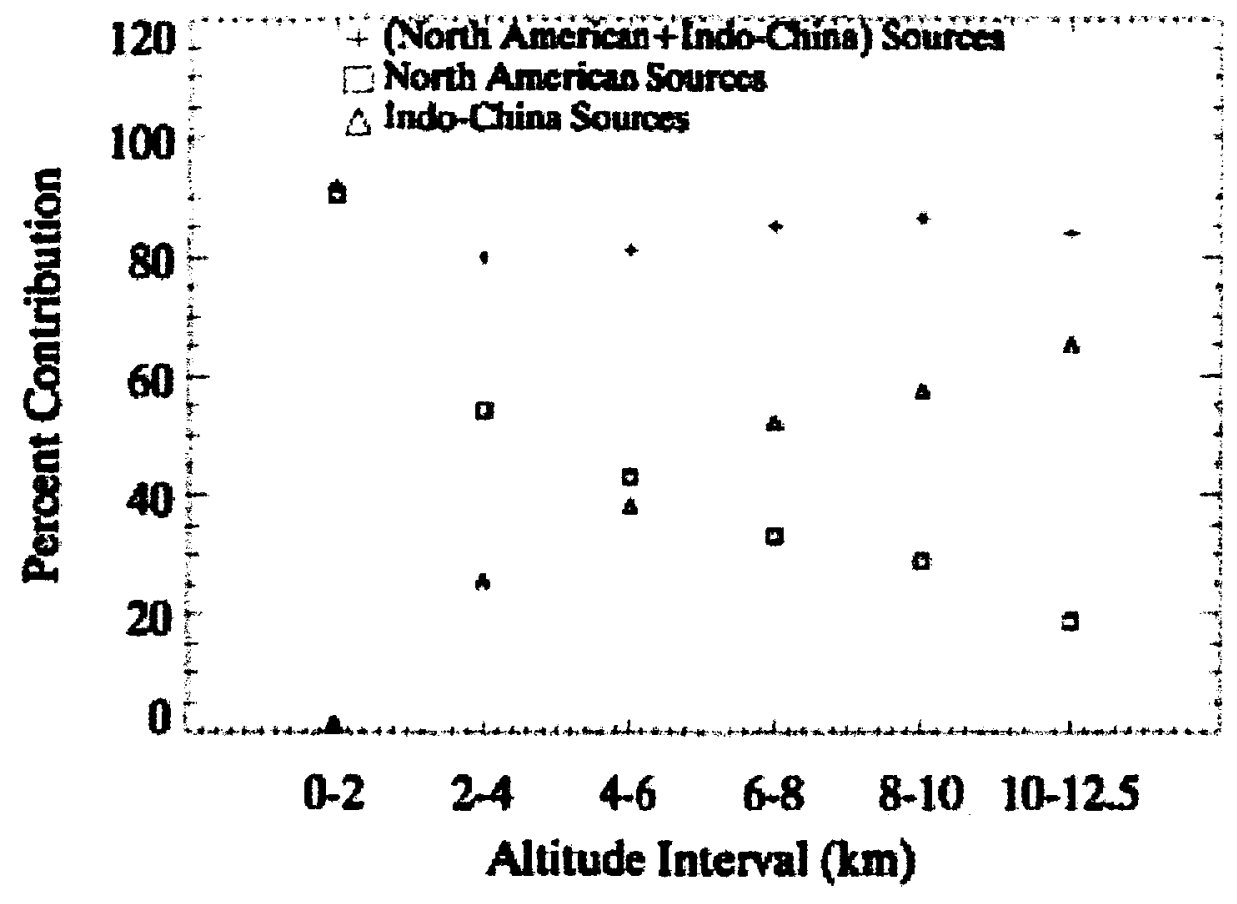

$f i x^{3}$ 


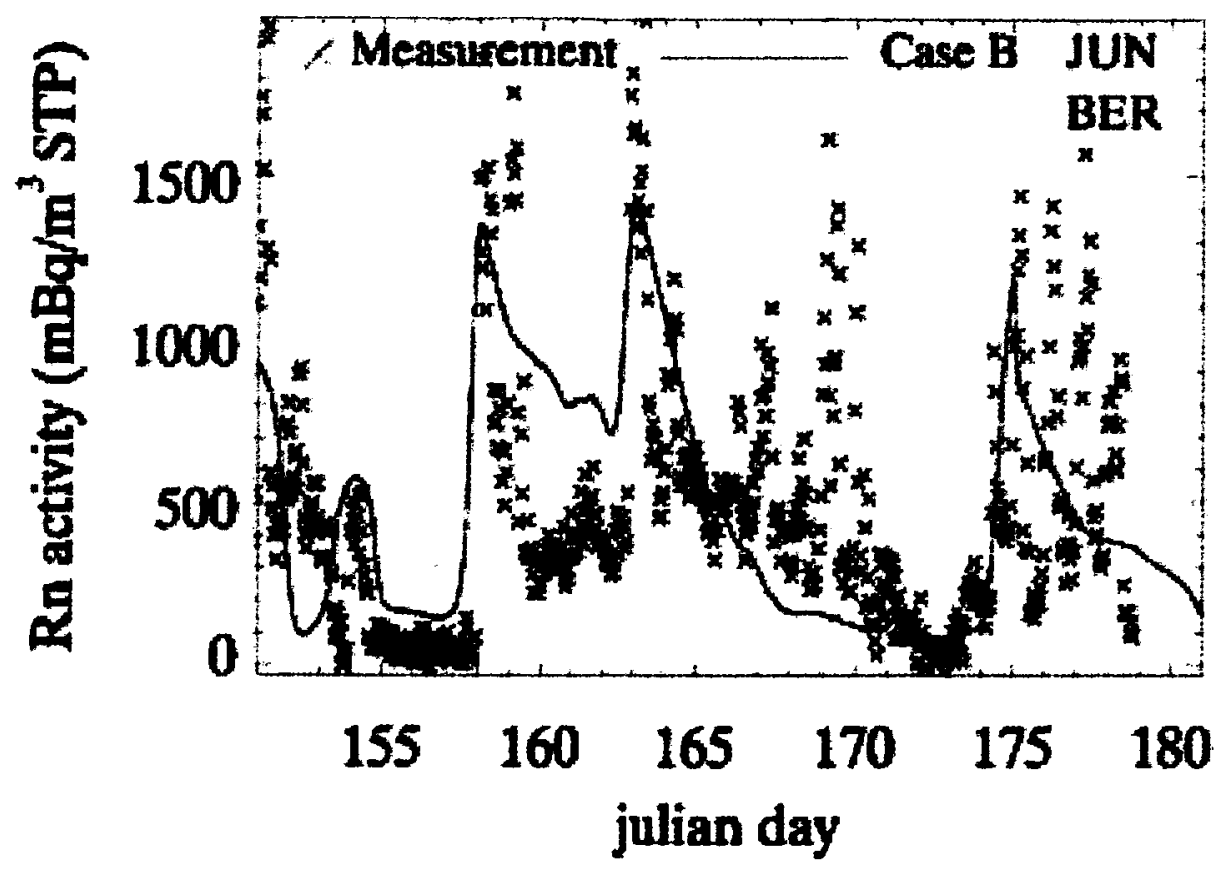

$\left(80^{4}\right.$ 


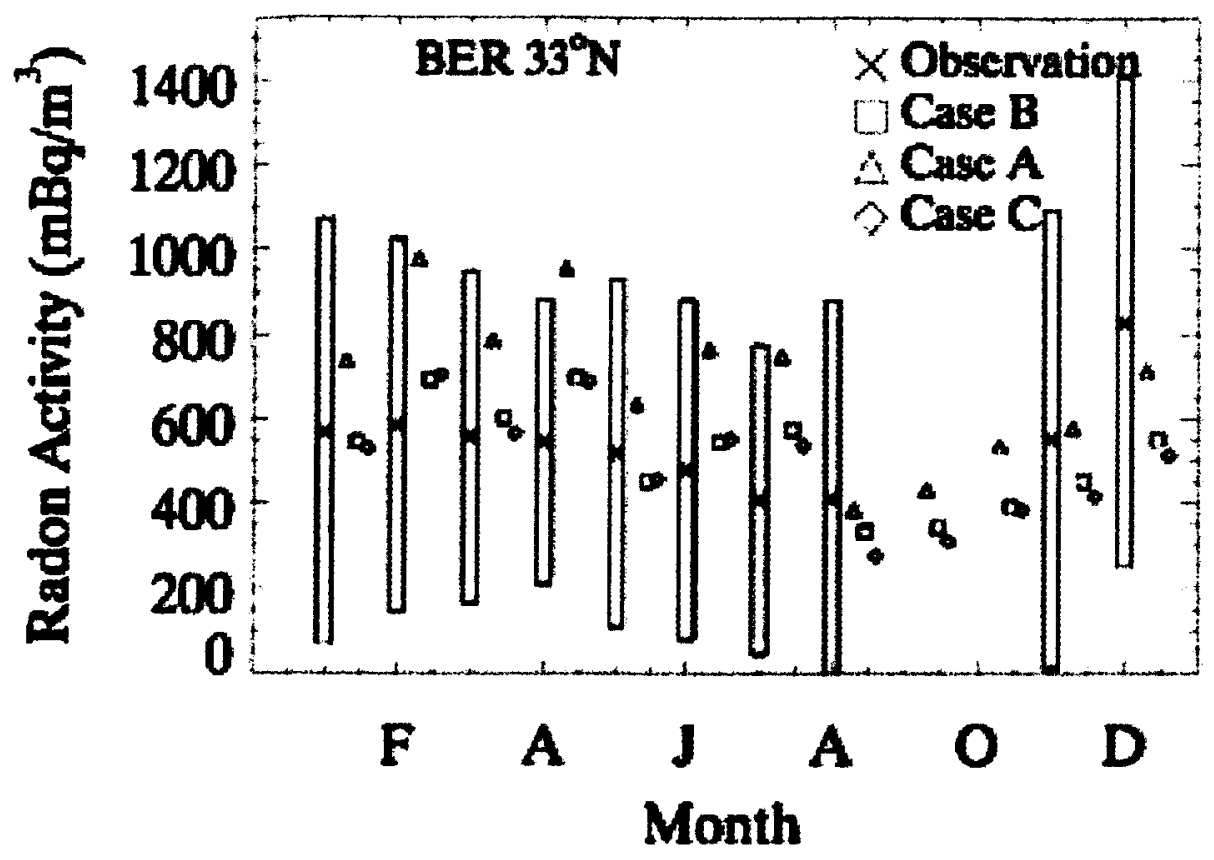

$(i n)^{2}$ 


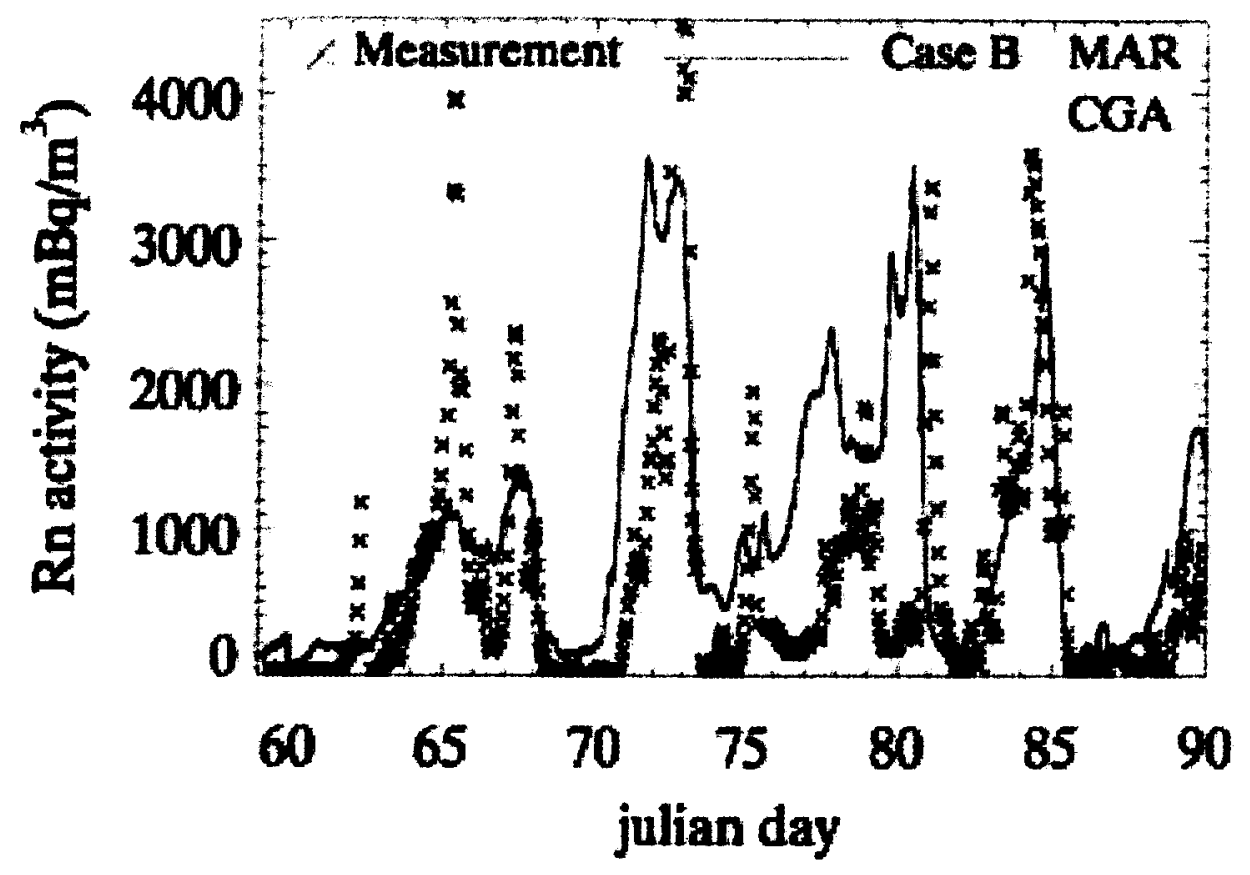

$8 i 0^{6 a}$ 


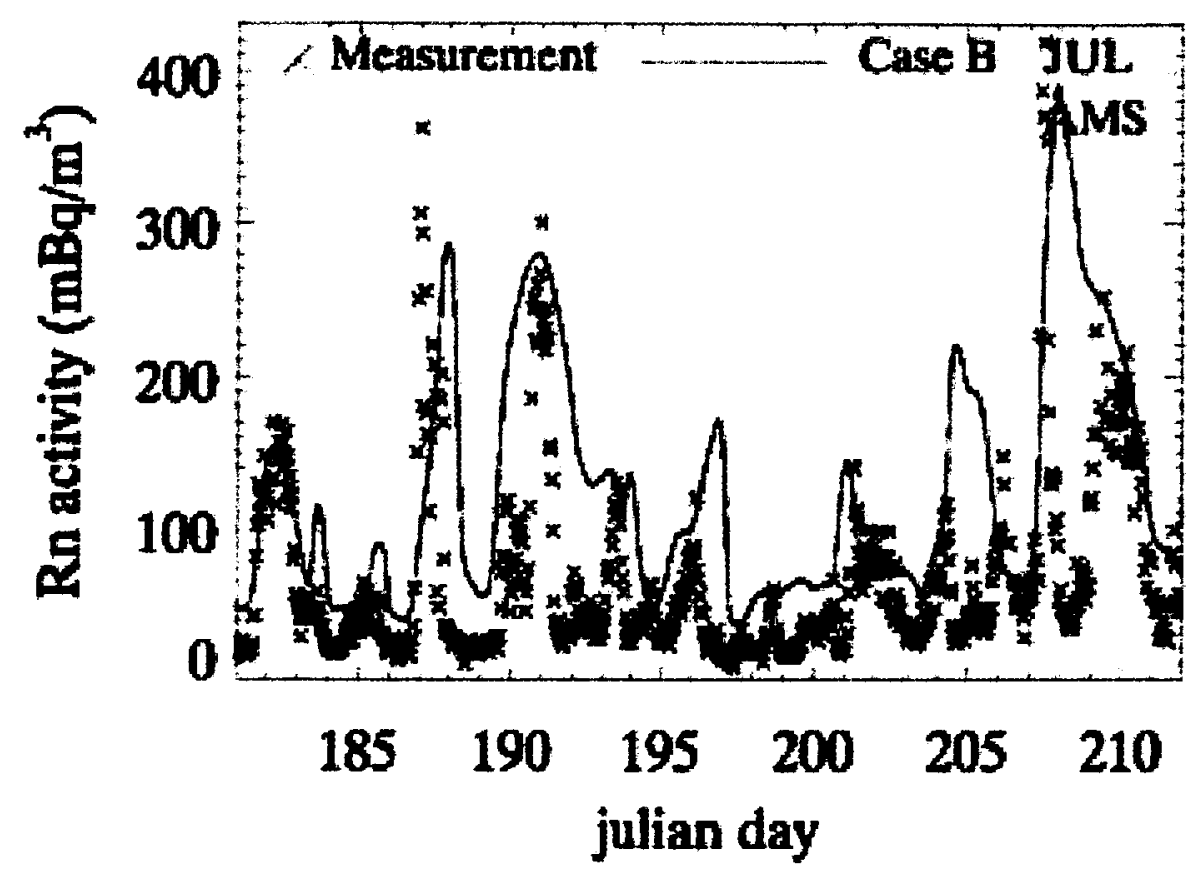

$(8)^{6 b}$ 


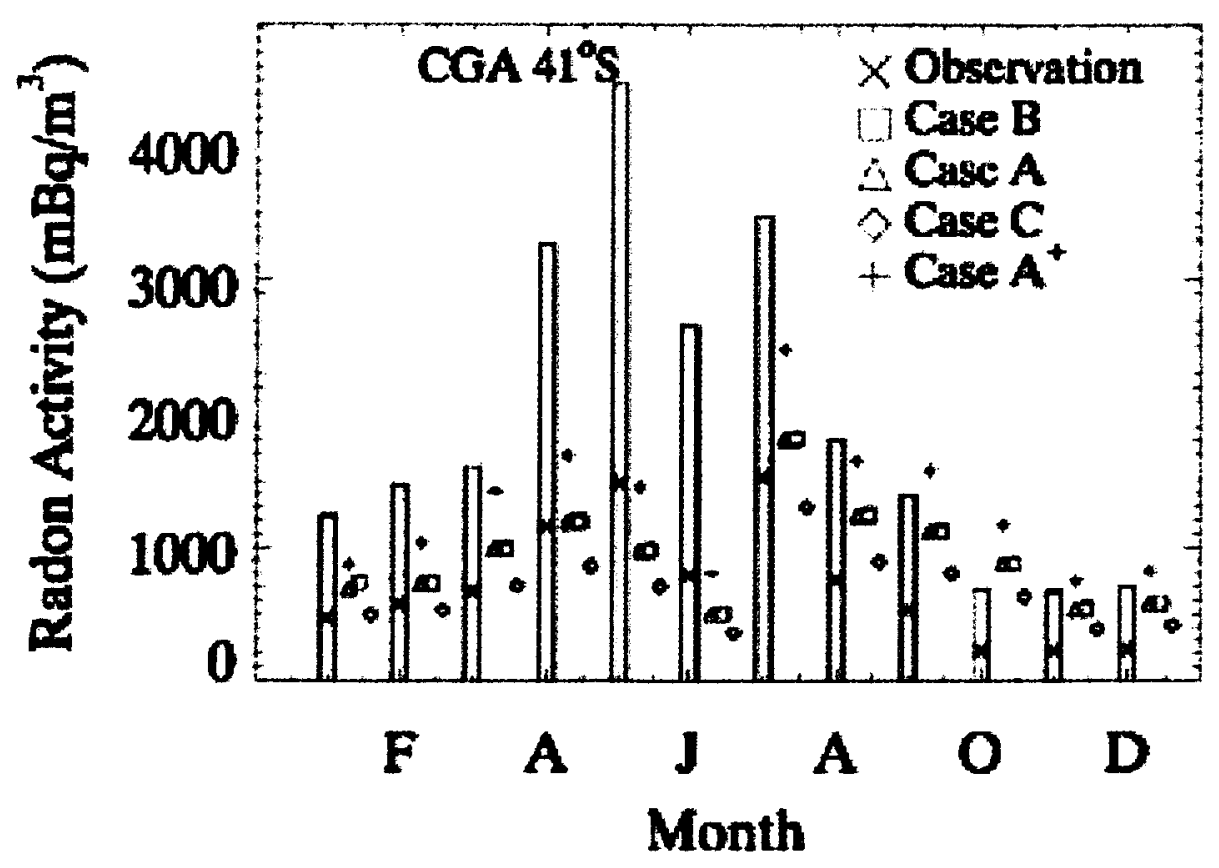

$\mathrm{Fig}^{\mathrm{a}}$ 


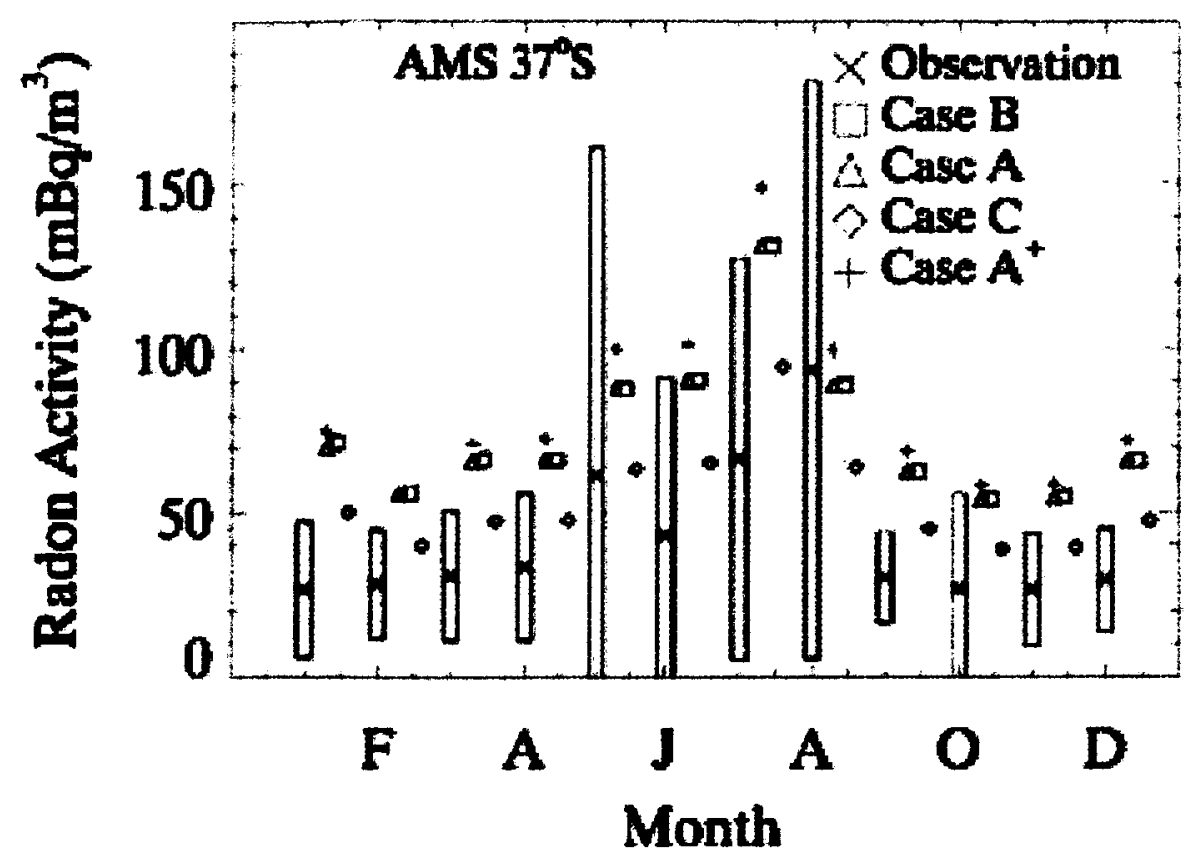

$6^{19} 7^{b}$ 


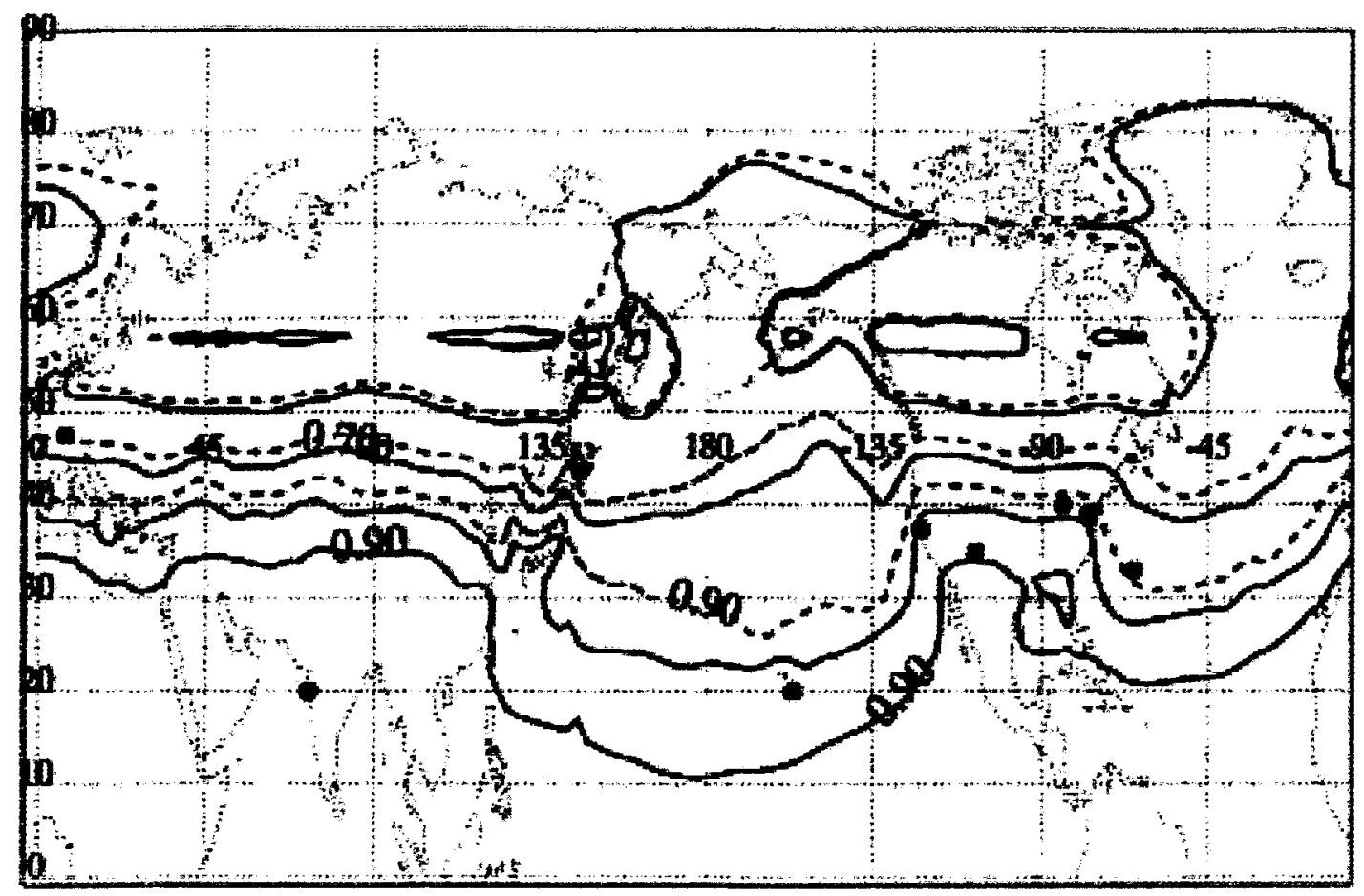

$\sin 8$ 


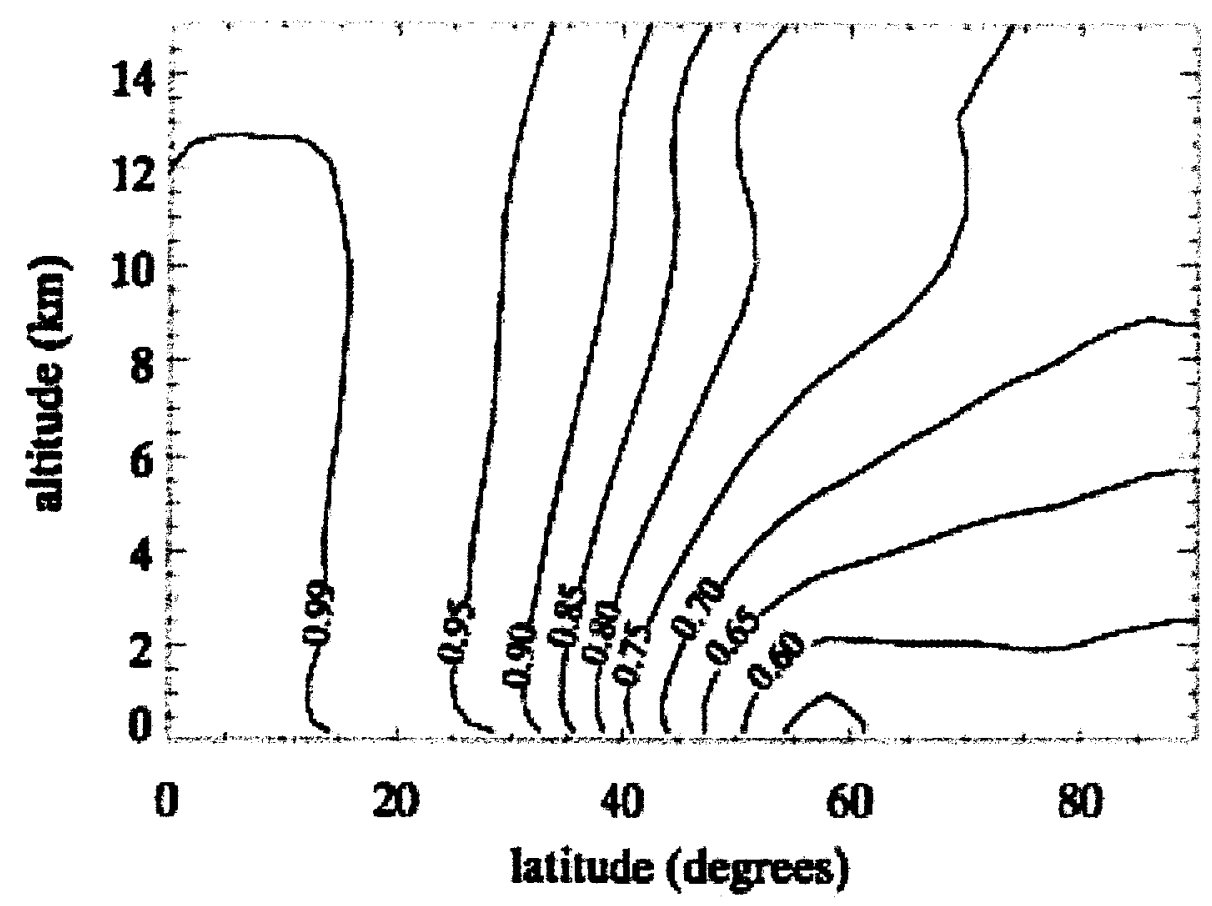

sig 9 


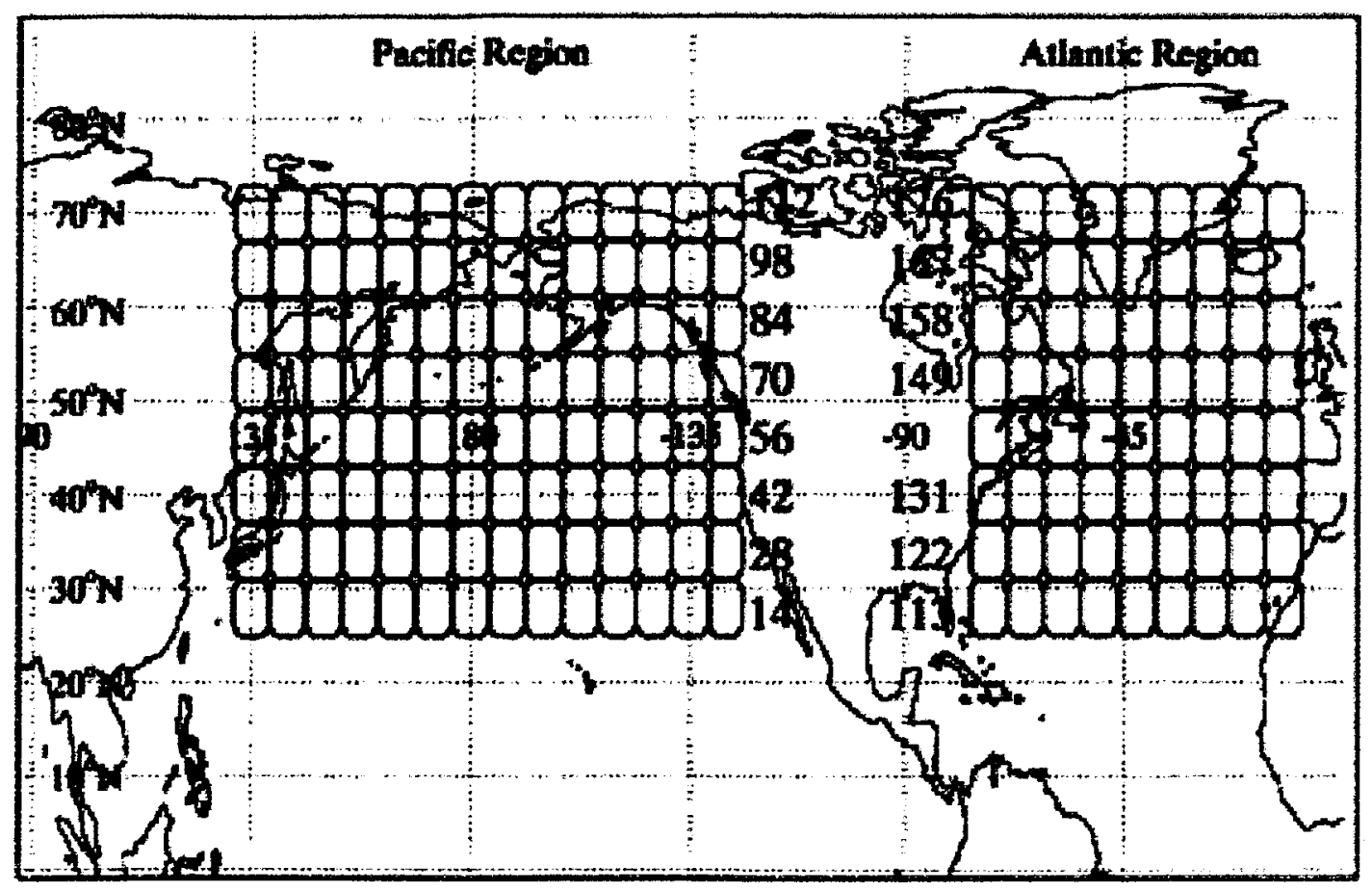

fig ${ }^{\circ}$ 


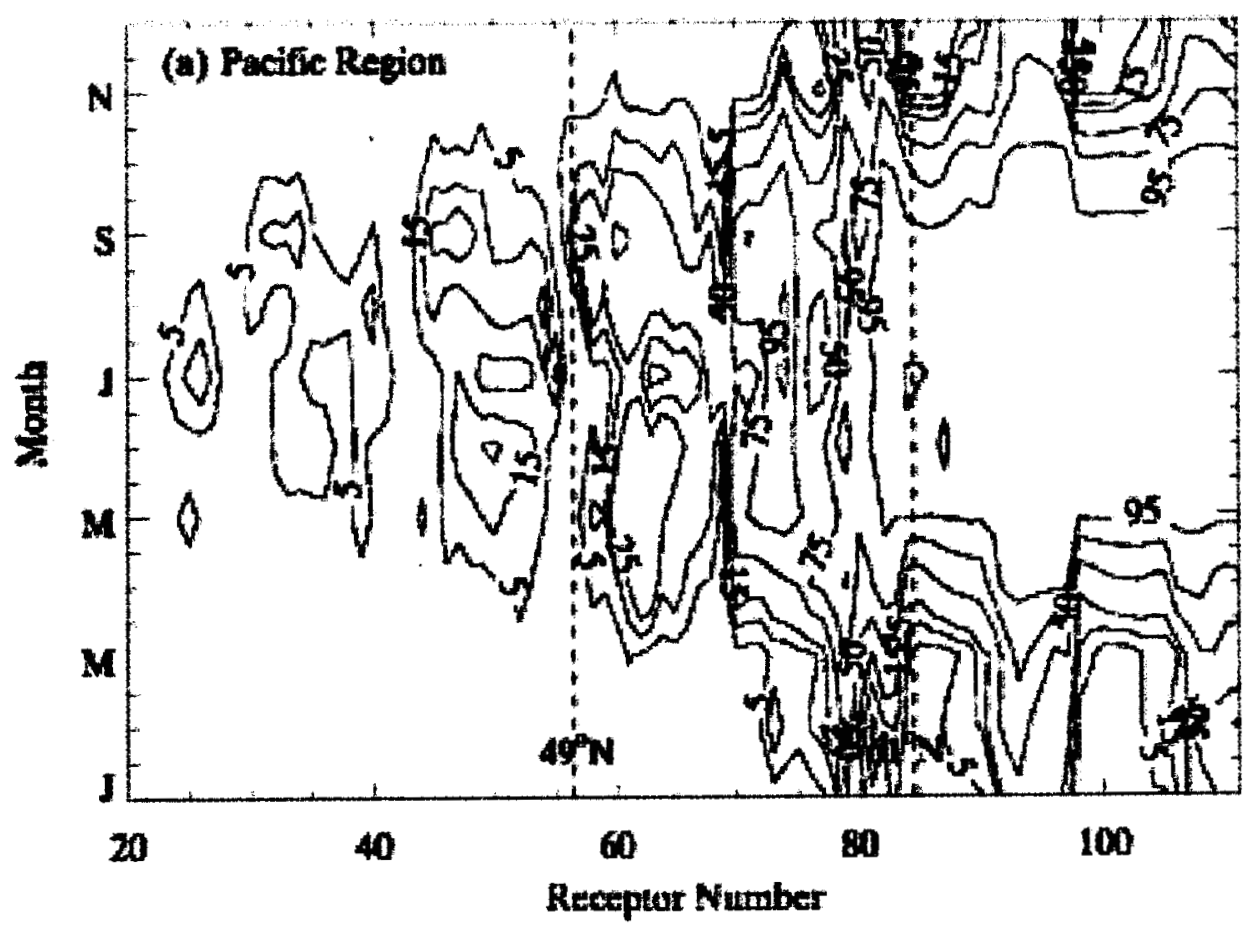

$60^{11 a}$ 


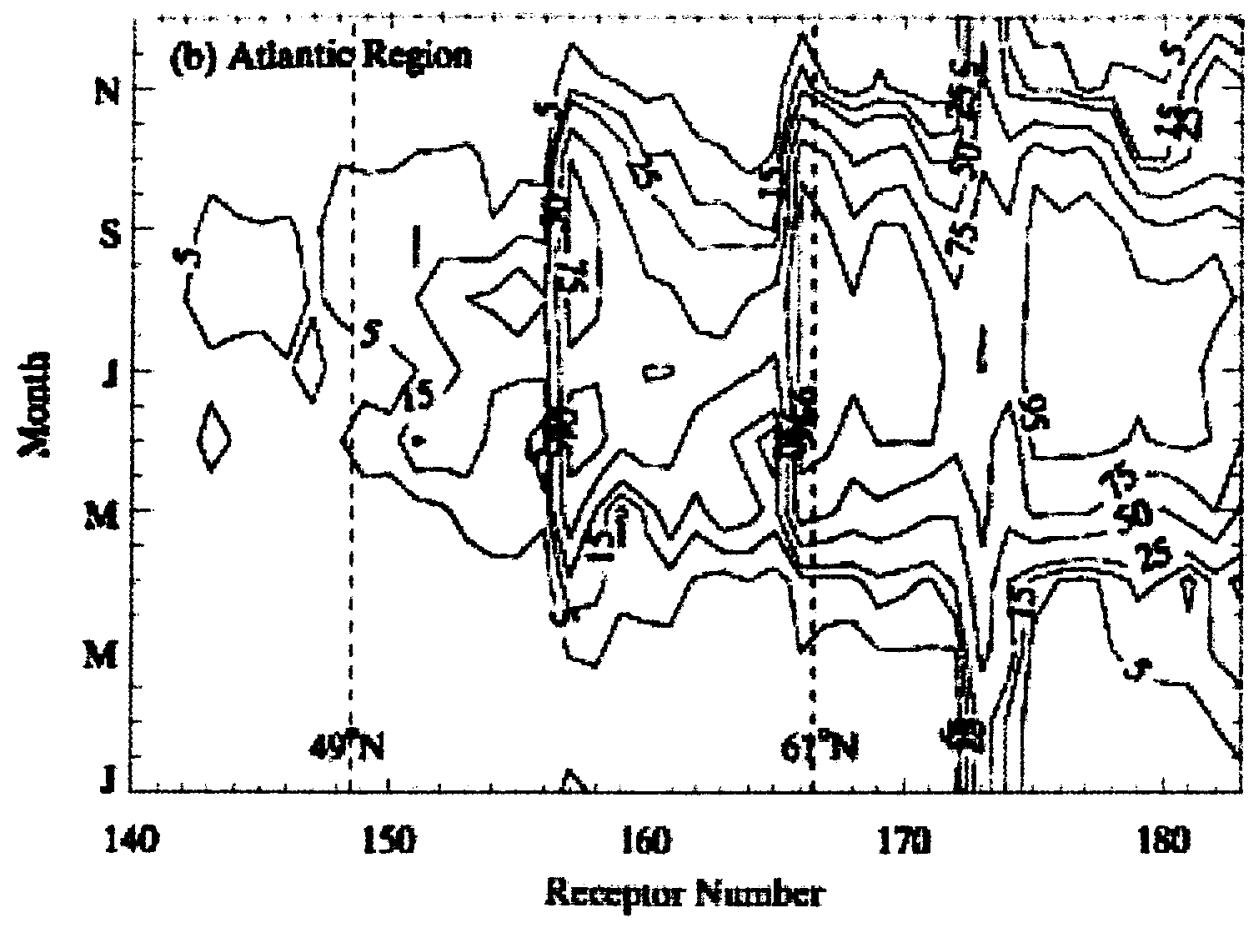

Sip $11 b$ 


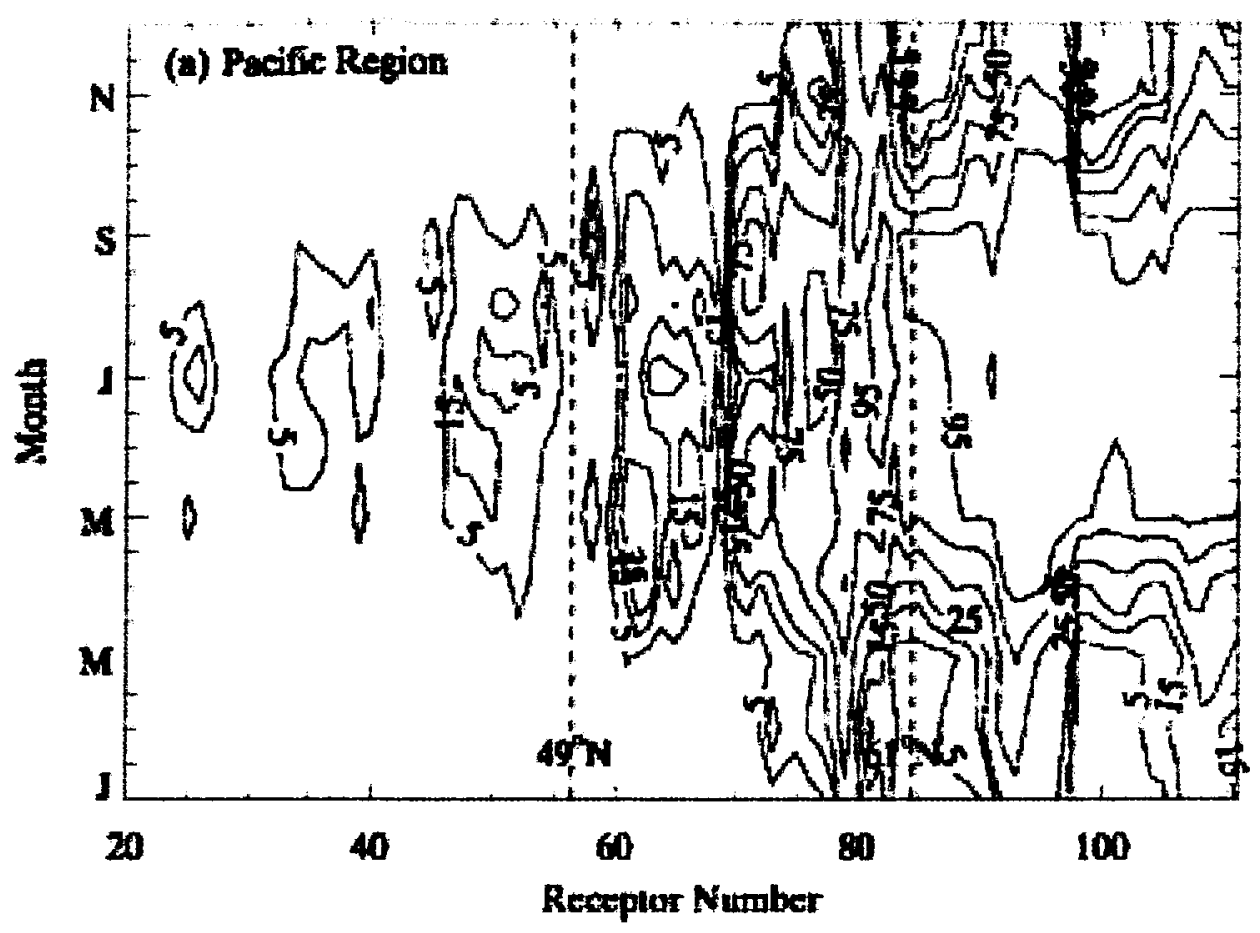

$\left(\right.$ sig $^{12}$ 


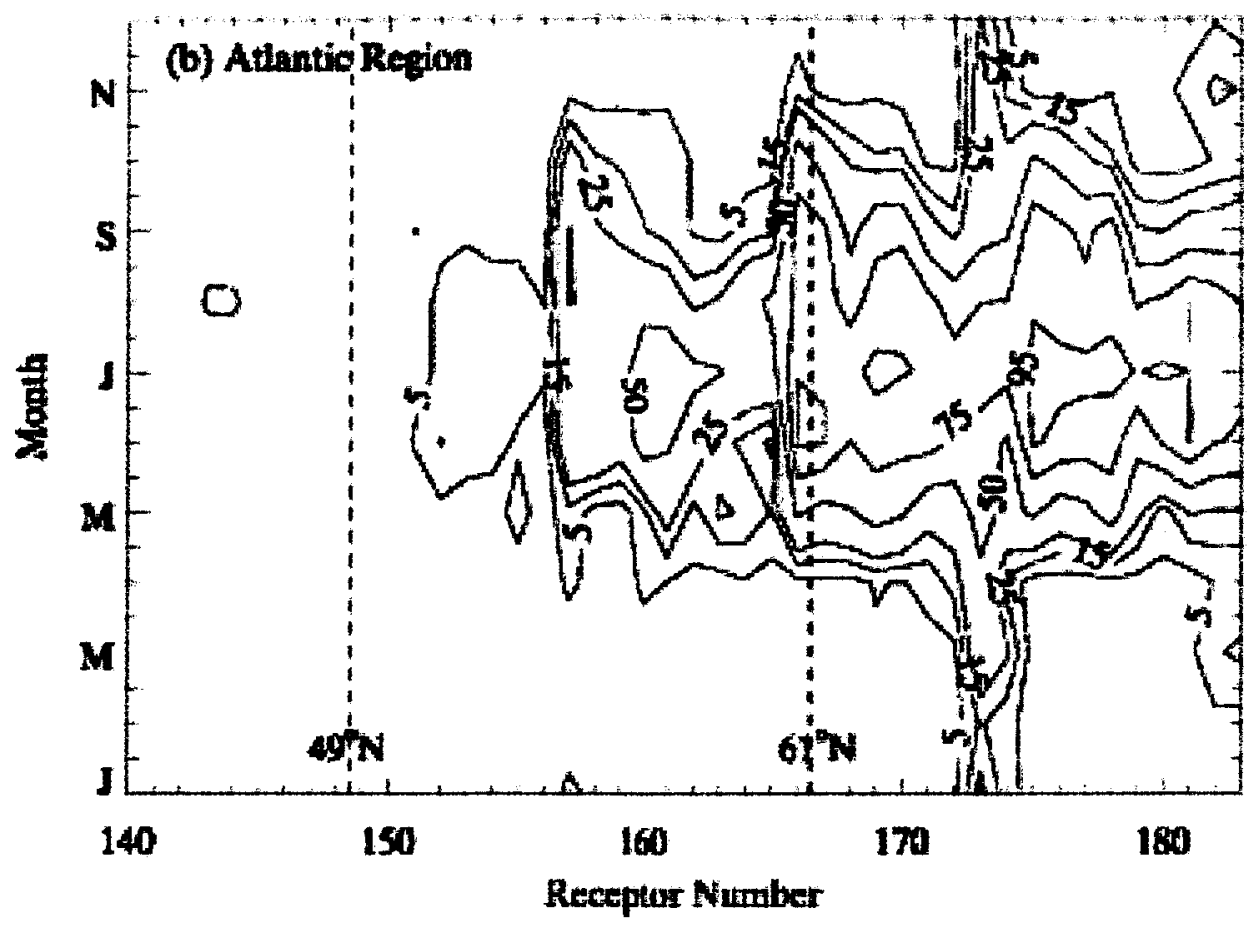

$(x)^{12 b}$ 